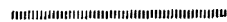

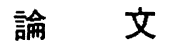 \\ UDC $669.187 .26: 621.365 .3: 669.046 .548 .2: 669.245$ \\ $\mathrm{Ni}$ 合金のエレクトロスラグ溶解における 活性元素の挙動についで
}

\author{
澤繁樹**.渋谷 正吾*** . 金原茂****
}

\section{On the Behavior of Active Elements during Electroslag Remelting Process of Ni-base Alloy}

Shigeki SAwA, Shohgo SHIBUYA, and Shigeru KINBARA

\begin{abstract}
Synopsis :
Behavior of such active elements as magnesium, aluminum and silicon during electroslag remelting process of a nickel-base alloy has been studied in a small scale ESR unit.

$\mathrm{CaF}_{2}$-base $\mathrm{Mg}^{++}$bearing slags of two or three components; $\mathrm{CaF}_{2}-\mathrm{MgO}, \mathrm{CaF}_{2}-\mathrm{MgF}_{2}, \mathrm{CaF}_{2}-\mathrm{MgO}_{2} \mathrm{Al}_{2} \mathrm{O}_{3}$, $\mathrm{CaF}_{2}-\mathrm{MgF}_{2}-\mathrm{Al}_{2} \mathrm{O}_{3}, \mathrm{CaF}_{2}-\mathrm{MgO}-\mathrm{AlF}_{3}, \mathrm{CaF}_{2}-\mathrm{MgO}-\mathrm{CaO}$ were compared with conventional $\mathrm{CaF}_{2}$ monoand $\mathrm{CaF}_{2}-\mathrm{Al}_{2} \mathrm{O}_{3}$ binary slags.

Several hundred ppm of magnesium was found in the ESR ingots remelted under slags containing suitable amount of $\mathrm{Mg}^{++}$and low $\mathrm{CaO}$ and $\mathrm{Al}_{2} \mathrm{O}_{3}$, although none of magnesium but aluminum or silicon was added to the original electrodes.

It was shown that the distribution ratio of magnesium between slag and metal was related to the concentration of $\mathrm{Al}^{++}+$in the slag, oxygen and aluminum in the metal.
\end{abstract}

\section{1. 緒言}

超耐熱合金をはじめとする $\mathrm{Ni}$ 合金鋳塊の製造にエレ クトロスラグ再溶解法 (ESR) の適用は近年増加の傾向 にあり，対象となる合金範囲も拡大しつつある。ESR に は， $\mathrm{Al} ， \mathrm{Ti}$ など活性元素の酸化損失の問題があるが， 真空アーク再溶解 (VAR) 飞比較して, 鋳塊の表面性 状, 脱硫, 熱間加工性, 歩留およびこれらに附随して製 造コストの面で優れているため, 再溶解を要する $\mathrm{Ni}$ 基 合金の大部分は, VAR から ESR へ移行する可能性が 認められる12)3).

$\mathrm{Ni}$ 基合金仙微量の $\mathrm{Mg}$ を添加すると，高温での機械 的性質ならびに熱間加工性が著しく改善されることが明 らか化されている4)5．Mg は蒸気任が高く，また酸素 との親和力が大きいので，VAR あるいは ESR などの 再溶解鋳塊中に Mg の安定した量を含有させることは 相当困難なことである.

多くの $\mathrm{Ni}$ 基合金は $\mathrm{Al} ， \mathrm{Ti}$ などの活性元素を含み， その僅かな成分変動が合金特性に大きな影響を与えるの
で，ESR 過程におけるこれら活性元素の酸化損失を揤 制するため種々の手段が探られている。たとえば(i)ス ラグ面の不活性ガスによるシール677). (ii).電極のアル ミナペーストなどによるコーティング7)，(iii)溶解中の スラグの脱酸8，（iv）スラグ組成の改善, などである.

活性元素を含む合金の溶解には，とくに酸素ポテンシ アルの低いスラグを使うことが要求され，酸化物を含ま ない $\mathrm{CaF}_{2}$, 化学的に比較的安定なアルミナを含む $\mathrm{CaF}_{2}-$ $\mathrm{Al}_{2} \mathrm{O}_{3}$ 系, あるいは $\mathrm{Ti}$ 含有合金の溶解に, これらに $\mathrm{TiO}_{2}$ を添加したスラグ1)6) などが使用されている。し かし $\mathrm{CaF}_{2}$ スラグは, MitchelL9)らが述へているよう に，電気伝導度が大きいために，鋳塊表面性状に問題が あり，また $\mathrm{CaF}_{2}-\mathrm{Al}_{2} \mathrm{O}_{3}$ 系スラグは活性元素の安定性 の面で必ずしも適当でない．またこれらスラグに関する 従来の研究では，Mg に関しては全く触れられていな い.

著者らは，実験室的小型 ESR 炉を用いて $\mathrm{Ni}$ 基合金 の再溶解特性に及ぼすスラグ組成の影響,ならびに $\mathrm{Mg}$, $\mathrm{Al}$ および Si など活性元素の 挙動に及ぼすスラグ組成

* 昭和52年 2 月 25 日曼付 (Received Feb. 25，1977)

**大同特殊鋼 (怢) 工博 (Daido Steel Co. Ltd., 1-7-13 Nishi shinbashi Minato-ku Tokyo 105)

*** (株)アイコ一 (Aikoh Co. Ltd.)

*****大同特殊鋼(株)渋川工場 (Shibukawa Works, Daido Steel Co. Ltd., ) 
および電極の酸素濃度の影響を検討した。主として用い たスラグは， $\mathrm{MgO}, \mathrm{MgF}_{2}$ など $\mathrm{Mg}^{++}$を含むもので， 組成を適当に撰択すれば, $\mathrm{CaF}_{2}$ スラグの欠点である発 熱量不足による鋳塊表面肌の悪化を改善し，またスラグ から適量の $\mathrm{Mg}$ を安定して 鋳塊に移行させることが可 能となつた.

\section{2. 実験装置および方法}

本実験に使用した交流 ESR 炉の装置の概略を Fig. 1 に示す. 銅製モールド10の寸法は内径 $50 \mathrm{~mm}$, 高さ 300 $\mathrm{mm}$ で, 消耗電極(9)直径は $30 \mathrm{~mm}$ であり（電極・モ ールド直径比 0.6), 電源トランスの二次定格容量は 50 V-600A である. 消耗電極の昇降は可変速モーター (1) によつておこなう。

試験には主に AMS 5754 (Hastelloy X) 相当の化学 成分を有する $\mathrm{Ni}$ 基合金を（Table 1) 用いた. 消耗電 極は $26 \mathrm{~kg}$ の真空誘導溶解による鋳塊あるいは $8 \mathrm{~kg} の$ 大気誘導溶解による鋳塊を $35 \mathrm{~mm} \phi$ に鉎伸し， $30 \mathrm{~mm} \phi$

1. Ringcone
2. Reducing gear
3. Coupling
4. Shaft for driving
electrode
5. Stationary support
6. Insulator
7. Stub
8. Lead wire
9. Electrode
10. Mould liner
11. Insulator
12. Mould stool

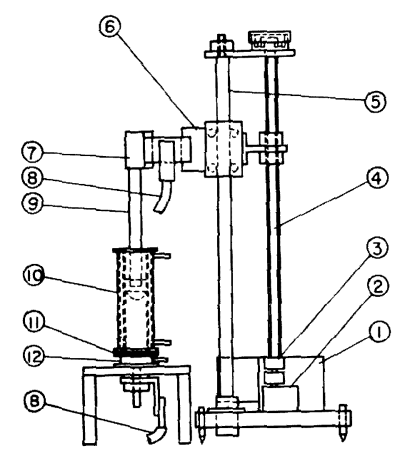

Fig. 1. Experimental apparatus.

Table 2. The types of slag used for experiment

\begin{tabular}{l|l}
\hline 1. Component & $\mathrm{CaF}_{2}$ \\
\hline 2. Components & $\begin{array}{l}\mathrm{CaF}_{2}-\mathrm{Al}_{2} \mathrm{O}_{3}, \mathrm{CaF}_{2}-\mathrm{MgF}_{2} \\
\mathrm{CaF}_{2}-\mathrm{MgO}\end{array}$ \\
\hline 3. Component & $\begin{array}{l}\mathrm{CaF}_{2}-\mathrm{MgF}_{2}-\mathrm{Al}_{2} \mathrm{O}_{3} \\
\mathrm{CaF}_{2}-\mathrm{MgO}-\mathrm{Al}_{2} \mathrm{O}_{3} \\
\mathrm{CaF}_{2}-\mathrm{MgO}-\mathrm{AlF}_{3} \\
\mathrm{CaF}_{2}-\mathrm{MgO}-\mathrm{CaO}\end{array}$ \\
\hline
\end{tabular}

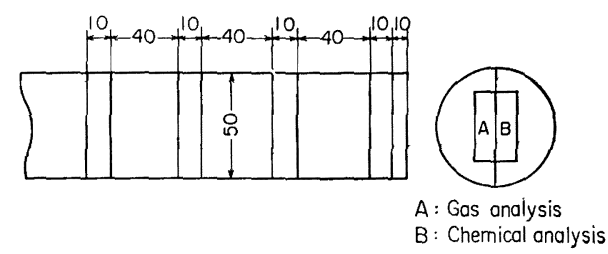

Fig. 2. Sampling position of the ESR ingot.

に旋削加工して製作した， Mg は ESR の過程でスラグ 成分の $\mathrm{MgO}$ あるいは $\mathrm{MgF}_{2}$ が還元されることにより， メタル中に移動することを意図し，またその可能性を検 討することが本実験の目的の一つであつたので大部分の 電極中には Mgを添加しなかつた。

実験に供したスラグ系を Table 2 に示す. スラグ組 成には $\mathrm{CaF}_{2}$ の一元系, $\mathrm{CaF}_{2}-\mathrm{MgO}$ および $\mathrm{CaF}_{2}-\mathrm{MgF}_{2}$ の二元系，あるいはこの二元系に $\mathrm{Al}_{2} \mathrm{O}_{3}, \mathrm{AlF}_{3}, \mathrm{CaO}$ などを添加した多成分系スラグを用い，一回のスラグの 投入量は $400 \mathrm{~g}$ に一定にした。着火時にその約 6 割を 投入し，スラグプールが形成された後漸時残量を追加し た.なお溶解速度は $167 \mathrm{~g} / \mathrm{min}$ にほぼ一定に保つた。

溶解後の鋳塊は Fig. 2 に示すごとく一定間隔ごとに 厚さ $10 \mathrm{~mm}$ の円板を切断し，化学分析試料およびガス 分析試料索採取した。また溶解後のスラグは粉砕し䖝光 メ線分析に供した。

\section{3. 実 験 結 果}

\section{1 溶解特性, 鋳塊の表面性状および ESR 前後の成 分変動におよぼすスラグ組成の影響}

$3 \cdot 1 \cdot 1 \quad \mathrm{CaF}_{2}-\mathrm{MgF}_{2}$ 系, $\mathrm{CaF}_{2}-\mathrm{MgF}_{2}-\mathrm{Al}_{2} \mathrm{O}_{3}$ 系

（1）溶解特性，鋳塊の表面性状

$\mathrm{Al}_{2} \mathrm{O}_{3}$ を含有しない $\mathrm{CaF}_{2}-\mathrm{MgF}_{2}$ 二元采の場合には， 弗化物のみから成る組成のためにスラグの電気伝導度が 大きく, 溶解条件は低電圧, 高電流 $(20 \sim 25 \mathrm{~V}, 600 \sim 750$ A) となつてスラグの温度は上昇し難い. 一方,この二元 系に $\mathrm{Al}_{2} \mathrm{O}_{3}$ を添加した $\mathrm{CaF}_{2}-\mathrm{MgF}_{2}-\mathrm{Al}_{2} \mathrm{O}_{3}$ 三元系の場合 には, $\mathrm{Al}_{2} \mathrm{O}_{3}$ 添加量の増加に伴い電気伝導度が低下し， スラグ温度が上昇するため溶解条件は安定する. Photo. 1 に $\mathrm{CaF}_{2}-10 \% \mathrm{MgF}_{2}, \mathrm{CaF}_{2}-20 \% \mathrm{MgF}_{2}, \mathrm{CaF}_{2}-20 \% \mathrm{MgF}_{2}-$ $10 \% \mathrm{Al}_{2} \mathrm{O}_{3}$ スラグを使用した場合の鋳塊表面の外観を示

Table 1. Chemical composition of the material used for experiment.

\begin{tabular}{c|c|c|c|c|c|c|c|c|c|c|c}
\hline $\mathrm{C}$ & $\mathrm{Si}$ & $\mathrm{Mn}$ & $\mathrm{P}$ & $\mathrm{S}$ & $\mathrm{Ni}$ & $\mathrm{Cr}$ & $\mathrm{Mo}$ & $\mathrm{W}$ & $\mathrm{Co}$ & $\mathrm{Fe}$ \\
\hline $\begin{array}{c}0.05 \\
\sim 0.15\end{array}$ & $<1.00$ & $<1.00$ & $<0.040$ & $<0.030$ & bal. & $\begin{array}{l}20.50 \\
\sim 23.00\end{array}$ & $\begin{array}{l}8.00 \\
\sim 10.00\end{array}$ & $\begin{array}{r}0.20 \\
\sim 1.00\end{array}$ & $\begin{array}{r}0.50 \\
\sim 2.50\end{array}$ & $\begin{array}{c}17.00 \\
\sim 20.00\end{array}$ \\
\hline
\end{tabular}




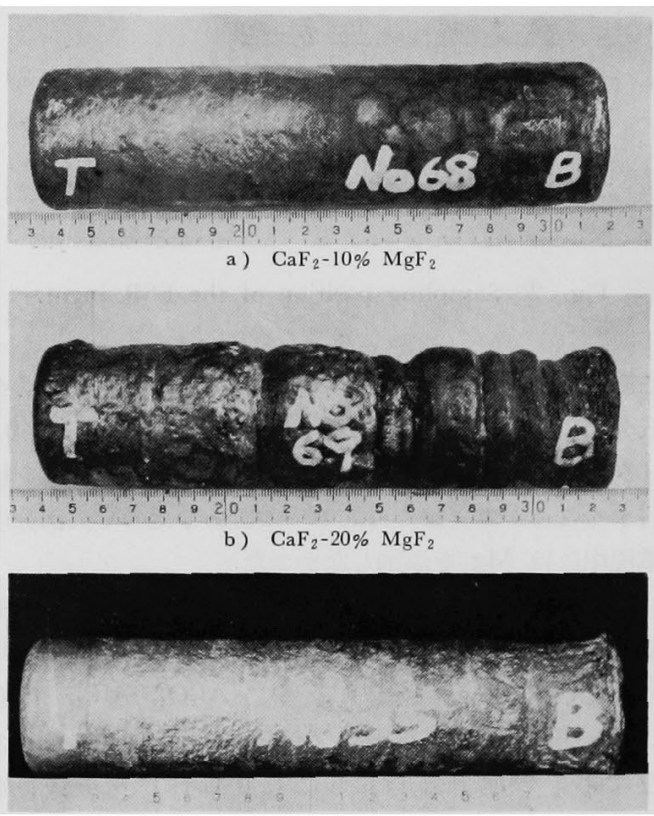

c) $\mathrm{CaF}_{2}-20 \% \mathrm{MgF}_{2}-10 \% \mathrm{Al}_{2} \mathrm{O}_{3}$

Photo. 1. Surface appearance of ESR ingots remelted by $\mathrm{CaF}_{2}-\mathrm{MgF}_{2}$ and $\mathrm{CaF}_{2}-$ $\mathrm{MgF}_{2}-\mathrm{Al}_{2} \mathrm{O}_{3}$ slag.

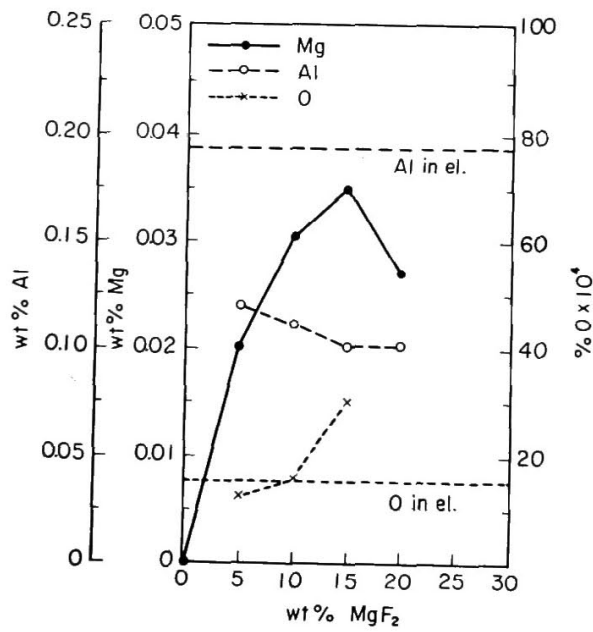

Fig. 3. Influence of $\mathrm{MgF}_{2}$ addition on the concentration of magnesium, aluminum and oxygen in ESR ingots in the case of $\mathrm{CaF}_{2}$ $\mathrm{MgF}_{2}$ slag.

す. 二元系の場合, $\mathrm{MgF}_{2}$ 添加量が $10 \%$ 以下では表面性 状が良奵であるが，それ以上になると slag skin が厚くな り性状が悪化する. 三元系の場合には $\mathrm{Al}_{2} \mathrm{O}_{3}$ 添加量の 増加江伴い溶解条件は高電圧, 低電流となり, $\mathrm{Al}_{2} \mathrm{O}_{3}$ 添

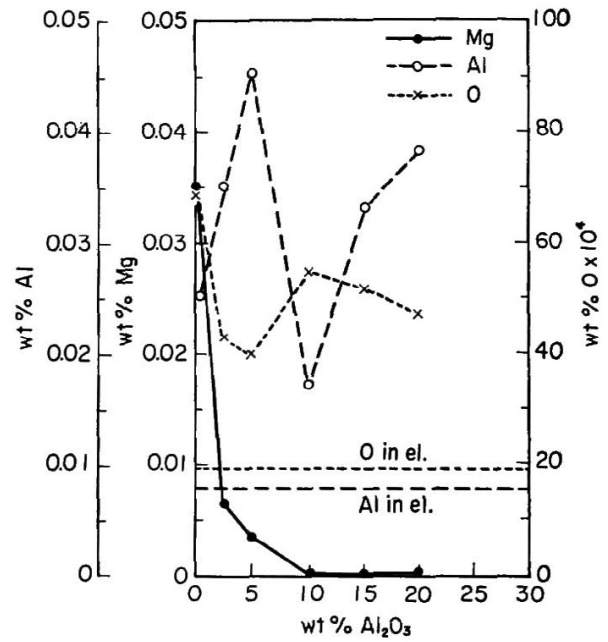

Fig. 4. Influence of $\mathrm{Al}_{2} \mathrm{O}_{3}$ addition on the concentration of magnesium, aluminum and oxygen in ESR ingots in the case of $\mathrm{CaF}_{2}-$ $10 \% \mathrm{MgF}_{2}-\mathrm{Al}_{2} \mathrm{O}_{3}$ slag.

加量が $10 \%$ 以上になると $\mathrm{MgF}_{2}$ 量が $20 \%$ まで増加し ても表面性状が良好な鋳塊が得られた.

(2) $\mathrm{Mg}, \mathrm{Al}, \mathrm{O}$ の挙動

$\mathrm{CaF}_{2}-\mathrm{MgF}_{2}$ 二元系スラグの場合の $\mathrm{MgF}_{2}$ の増加に伴 つた ESR 前後の $\mathrm{Mg}, \mathrm{Al}, \mathrm{O}$ の挙動を Fig. 3 に示 す. 本実験では前述したごとくすべて $\mathrm{Mg}$ が無添加の 電極を使用したが， $\mathrm{MgF}_{2}$ 添加量が 15\% 以下ではこれ の増加に伴い ESR 後の Mg 濃度は増加する傾向にあ り，最大 $0.0348 \%$ の $\mathrm{Mg}$ がスラグからメタルへ移動 することが認められる. O 濃度は $\mathrm{MgF}_{2}$ の增加に伴 い增加し, $\mathrm{Al}$ 濃度は逆に減少する. Fig. 4 には三元采 スラグを使用し， $\mathrm{MgF}_{2}$ 添加量を $10 \%$ に一定にした条 件下での $\mathrm{Mg}, \mathrm{Al}, \mathrm{O}$ の挙動におよぼす $\mathrm{Al}_{2} \mathrm{O}_{3}$ 添加量 の影響を示す. $\mathrm{Al}_{2} \mathrm{O}_{3}$ 添加量が増加すると ESR 後の $\mathrm{Mg}$ 増加量は減少し, $\mathrm{Al}_{2} \mathrm{O}_{3}$ が $10 \%$ 以上ではスラグか らメタルへの $\mathrm{Mg}$ の移動は全く認められなくなる.

$3.1 .2 \mathrm{CaF}_{2}-\mathrm{MgO}, \mathrm{CaF}_{2}-\mathrm{MgO}-\mathrm{Al}_{2} \mathrm{O}_{3}$ 系

（1）溶解特性, 鋳塊の表面性状

$\mathrm{CaF}_{2}-\mathrm{MgO}$ 系スラグおよび $\mathrm{CaF}_{2}-\mathrm{MgO}-\mathrm{Al}_{2} \mathrm{O}_{3}$ 䎹ス ラグを使用した場合の鋳塊の表面性状の例を Photo. 2 に示す. $\mathrm{CaF}_{2}-\mathrm{MgO}$ 二元系の場合には $\mathrm{MgO}$ 添加量が $10 \%$ 以下の範囲内で溶解条件は安定しているが, $\mathrm{MgO}$ 添加量の増加に伴ない slag skin が厚くなり表面性状は 劣化する. $\mathrm{CaF}_{2}-\mathrm{MgO}$ 系の共晶組成 $(10 \% \mathrm{MgO})$ より 過共晶の $\mathrm{CaF}_{2}-20 \% \mathrm{MgO}$ の場合には, 初晶 $\mathrm{MgO}$ か 晶出する液相線温度が上昇するため, slag skin の厚さ 


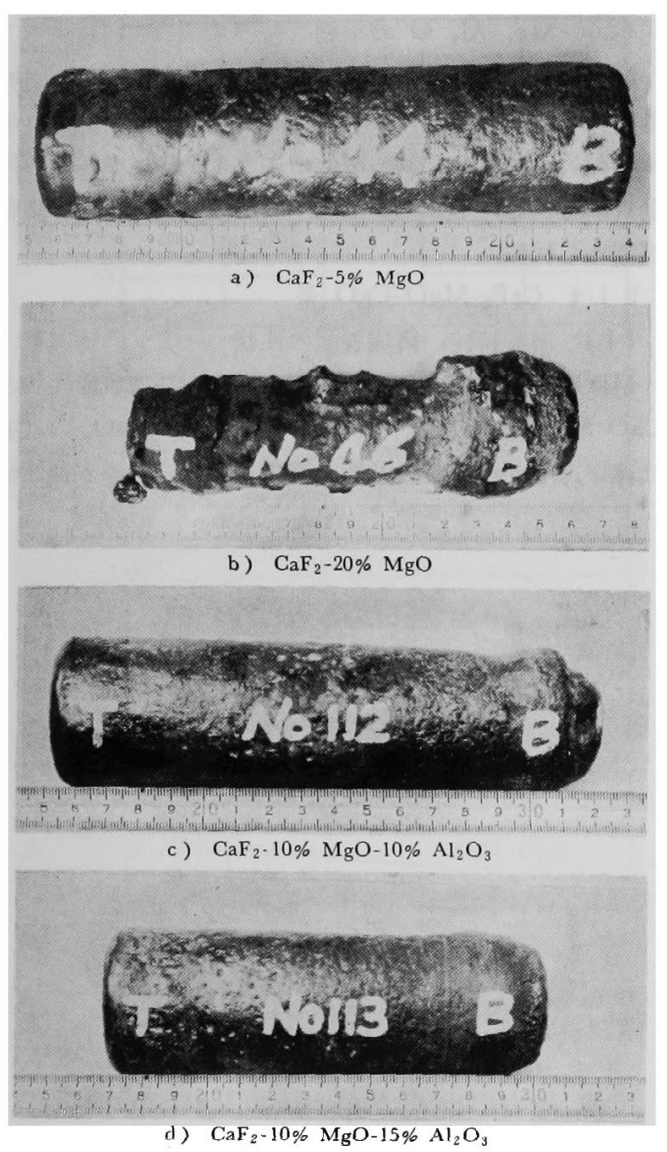

Photo. 2. Surface appearance of ESR ingots remelted by $\mathrm{CaF}_{2}-\mathrm{MgO}$ and $\mathrm{CaF}_{2}-$ $\mathrm{MgO}-\mathrm{Al}_{2} \mathrm{O}_{3}$ slag.

が著しく増加する．この二元系に $\mathrm{Al}_{2} \mathrm{O}_{3}$ を添加すると スラグの電気伝導度の低下によりスラグ温度が上昇し溶 解条件は安定する. $\mathrm{MgO}$ 添加量か 10\% 一定の場合に は Photo. 2 (c), (d) のごとく $\mathrm{Al}_{2} \mathrm{O}_{3}$ 添加量の増加に 伴い鋳塊の表面性状浪好になる。

(2) $\mathrm{Mg}, \mathrm{Al}, \mathrm{O}$ の挙動

$\mathrm{CaF}_{2}-\mathrm{MgO}$ 二元系スラグを用いた場合の $\mathrm{MgO}$ 添加 量と ESR 前後の $\mathrm{Mg}, \mathrm{Al}, \mathrm{O}$ 濃度変化の関係 Fig. 5 に示す. $\mathrm{MgO}$ 添加量が $20 \%$ までの範囲内で ESR 後 の $\mathrm{Mg}$ 濃度は $\mathrm{MgO}$ 添加量の増加に伴い増加すること が認められる. ESR 後のO 濃度は電極中の濃度より 著しく減少するが，MgO 添加量の增加に伴ない増加す る傾向が認められる.

$\mathrm{MgO}$ 添加量它 $10 \%$ に一定にした場合の $\mathrm{Al}_{2} \mathrm{O}_{3}$ 添 加量と $\mathrm{Mg}, \mathrm{Al}, \mathrm{O}$ 濃度溶化の関係觉 Fig. 6 亿示す. $\mathrm{CaF}_{2}-\mathrm{MgF}_{2}-\mathrm{Al}_{2} \mathrm{O}_{3}$ 三元系の 場合と同様に $\mathrm{Al}_{2} \mathrm{O}_{3}$ の増

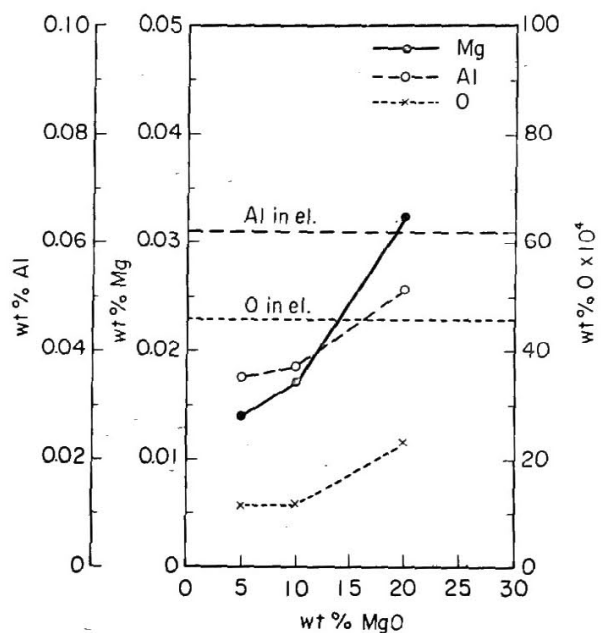

Fig. 5. Influence of $\mathrm{MgO}$ addition on the concentration of magnesium, aluminum and oxygen in ESR ingots in the case of $\mathrm{CaF}_{2}$ $\mathrm{MgO}$ slag.

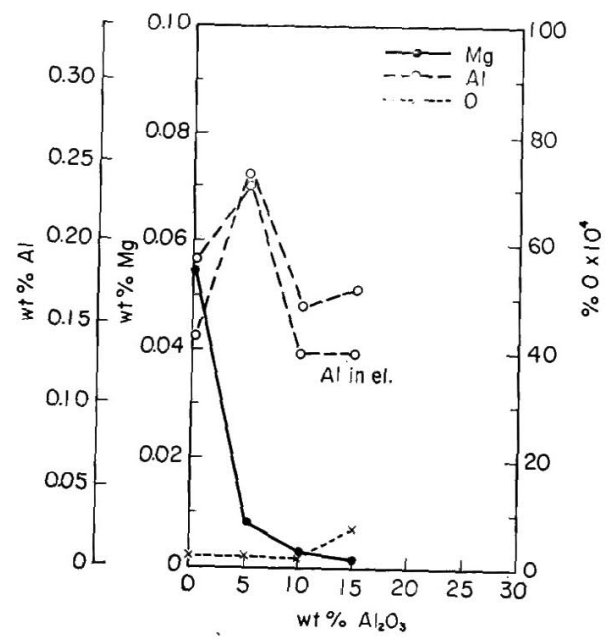

Fig. 6. Influence of $\mathrm{Al}_{2} \mathrm{O}_{3}$ addition on the concen tration of magnesium, aluminum and oxygen in ESR ingots in the case of $\mathrm{CaF}_{2-}$ $10 \% \mathrm{MgO}-\mathrm{Al}_{2} \mathrm{O}_{3}$ slag.

加に伴い鋳塊中の $\mathrm{Mg}$ 浱度は減少し, $\mathrm{O}$ 濃度は増加す る. $\mathrm{Al}_{2} \mathrm{O}_{3}$ 添加量が $15 \%$ 以上に増加すると，スラグか らメタルへの $\mathrm{Mg}$ の移動はほとえど認められなくなる。

$3 \cdot 1 \cdot 3 \quad \mathrm{CaF}_{2}-\mathrm{MgO}-\mathrm{AlF}_{3}$ 采

（1）溶解特性, 鋳塊表面の性状

溶解特性におよ注す $\mathrm{Al}_{2} \mathrm{~F}_{3}$ の影響は $\mathrm{Al}_{2} \mathrm{O}_{3}$ の場合々 ほぼ同等で，鋳塊表面肌の一例它 Photo. 3 に示すごと 


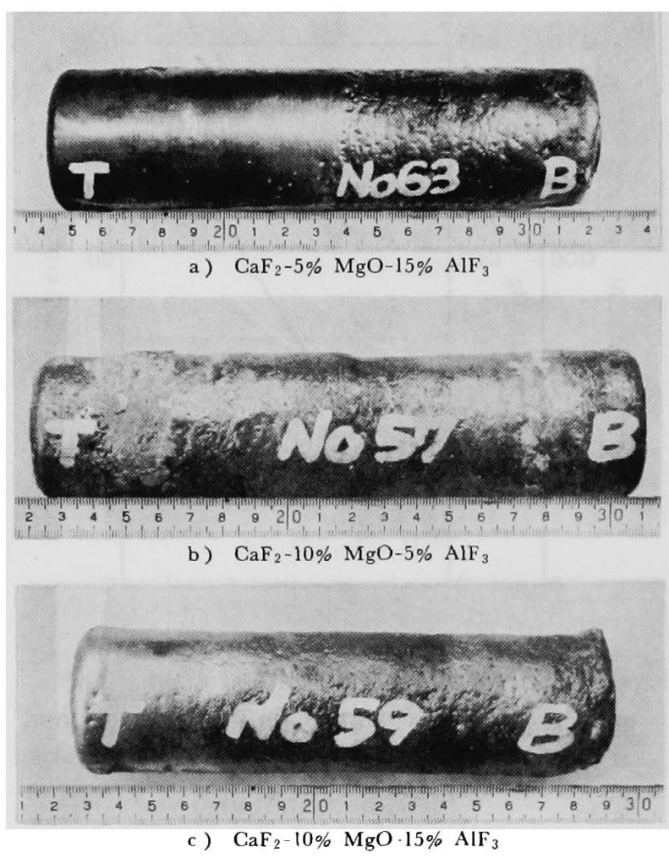

Photo. 3. Surface appearance of ESR ingots remelted by $\mathrm{CaF}_{2}-\mathrm{MgO}-\mathrm{AlF}_{3}$ slag.

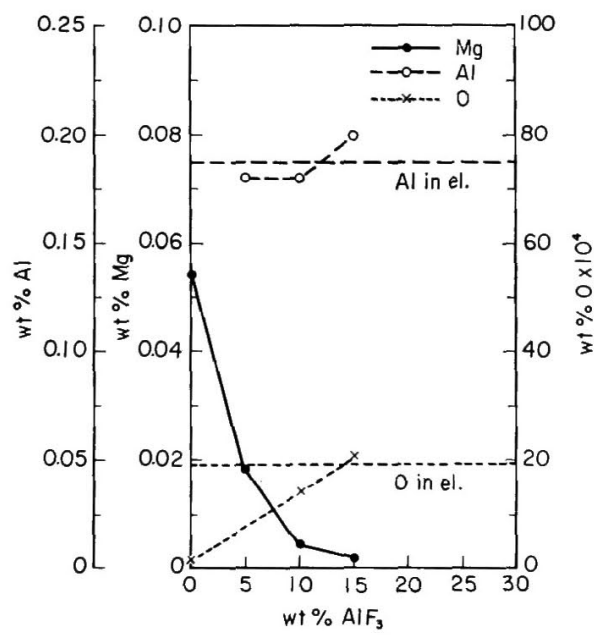

Fig. 7. Influence of $\mathrm{AlF}_{3}$ addition on the concentration of magnesium, aluminum and oxygen in ESR ingots in the case of $\mathrm{CaF}_{2-}$ $\mathrm{MgO}-\mathrm{AlF}_{3}$ slag.

$<\mathrm{MgO}$ 添加量が一定の場合には, $\mathrm{AlF}_{3}$ 添加量が增加 するに伴い溶解特性は向上し，鋳塊表面性状も良好とな る. 逆に $\mathrm{AlF}_{3}$ 添加量が一定の場合には $\mathrm{MgO}$ 添加量 の増加に伴い表面性状法劣化する.
(2) $\mathrm{Mg}, \mathrm{Al}, \mathrm{O}$ の挙動

$\mathrm{MgO}$ 添加量を 10\% に一定にした場台の $\mathrm{AlF}_{3}$ 添加 量と ESR 後の $\mathrm{Mg}, \mathrm{Al}, \mathrm{O}$ 濃度の関係を Fig. 7 に示 す. $\mathrm{AlF}_{3}$ の增加に伴い $\mathrm{Mg}$ のスラグからメタルへの移 動量は減少し, 逆に $\mathrm{Al}$ 濃度, $\mathrm{O}$ 濃度が増加する傾向 が認められる。

\section{$3 \cdot 1.4 \mathrm{CaF}_{2}-\mathrm{MgO}-\mathrm{CaO}$ 系}

（1）溶解特性，鋳塊表面の性状

$\mathrm{MgO}$ 添加量が 10\% に一定の場合の鋳塊表面性状と $\mathrm{CaO}$ 添加量の関係を Photo. 4 に示す. $\mathrm{CaO}$ の増加 に伴いスラグプール内で放電現象が䜑められ，表面性状

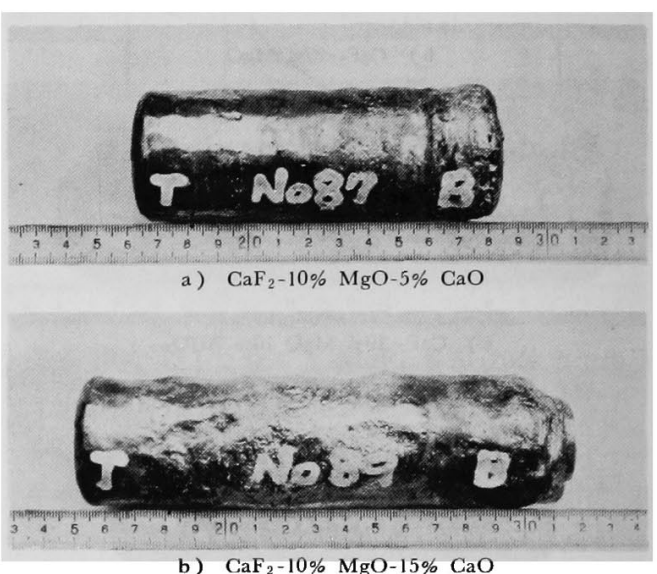

Photo. 4. Surface appearance of ESR ingots remelted by $\mathrm{CaF}_{2}-\mathrm{MgO}-\mathrm{CaO}$ slag.

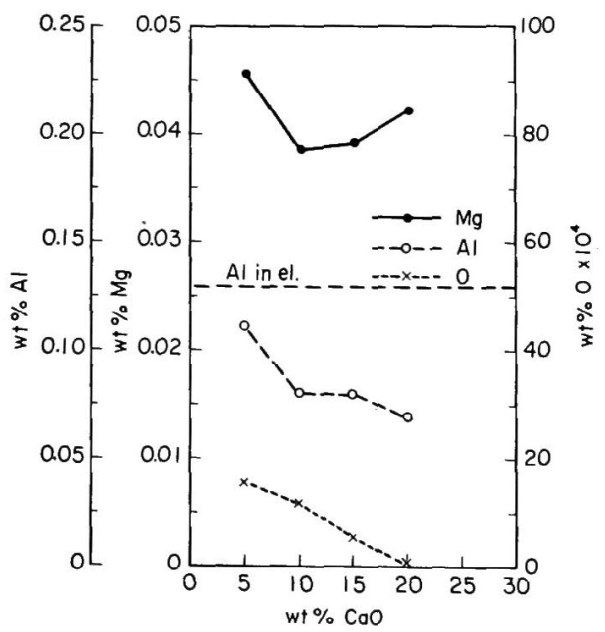

Fig. 8. Influence of $\mathrm{CaO}$ addition on the concentration of magnesium, aluminum and oxygen in ESR ingots in the case of $\mathrm{CaF}_{2}-$ $\mathrm{MgO}-\mathrm{CaO}$ slag. 


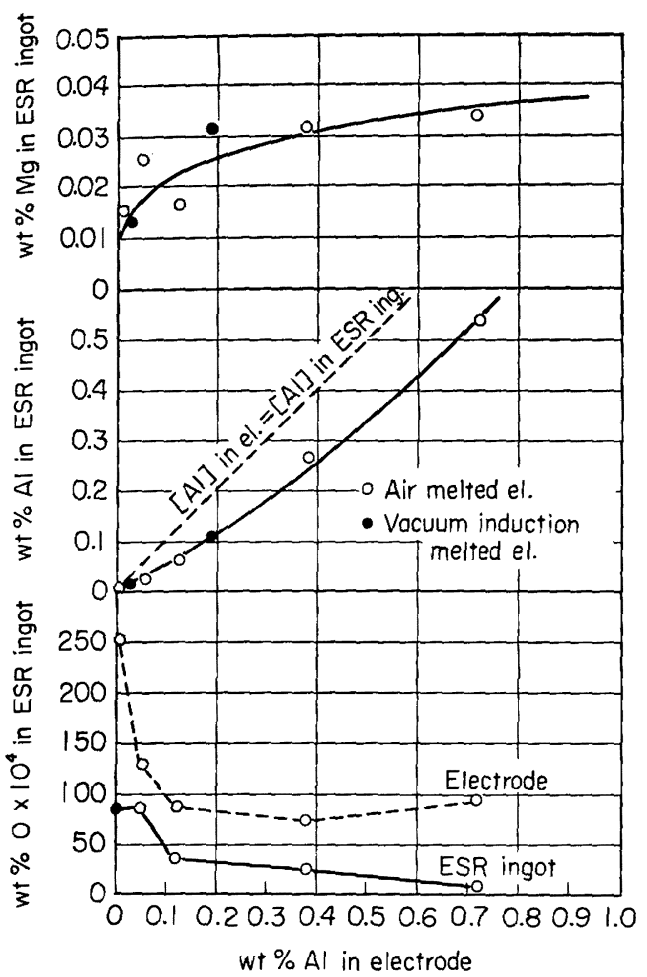

Fig. 9. Influence of the concentration of aluminum in the electrode on the concentration of magnesium, aluminum and oxygen in the ESR ingot in the cace of $\mathrm{CaF}_{2}-10 \% \mathrm{MgF}_{2}$ slag.

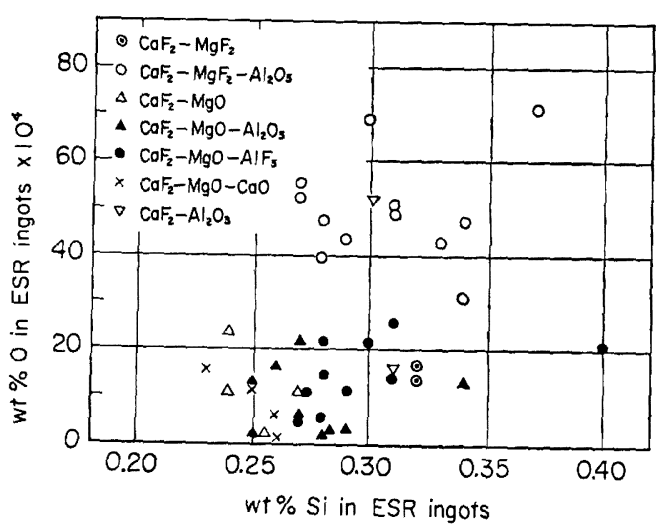

Fig. 10. Relation between the concentration of oxygen and silicon in the ESR ingot.

は劣化する傾向にある。

(2) $\mathrm{Mg}, \mathrm{Al}, \mathrm{O}$ の挙動

$\mathrm{MgO}$ 添加量が $10 \%$ の場合の $\mathrm{CaO}$ 添加量と $\mathrm{Mg}$,
$\mathrm{Al}, \mathrm{O}$ 濃度の関倸を Fig. 8 亿示す. ESR 鋳塊中の $\mathrm{Mg}$ 濃度と $\mathrm{CaO}$ 添加量の間には明膫な関係は認められず, $\mathrm{Mg}$ はスラグよりメタルヘ移動して最大 $0.045 \%$ に達 する. $\mathrm{Al}, \mathrm{O}$ 濃度は $\mathrm{CaO}$ 添加量の増加に 伴い減少す る.

\subsection{ESR 過程における Mg，O の挙動におよぼす電 柾中の $\mathbf{A 1}$ 謴度の影響}

電極の脱酸程度と ESR 鋳塊の $\mathrm{Mg}$ 濃度の関係を検 討する目的で大気あるいは真空誘導溶解炉によつて溶製 した電極の $\mathrm{Al}$ 濃度を最小 $0.005 \%$ 以下から最大 0.713 $\%$ まで 5 段階に変化させ， $\mathrm{MgF}_{2}$ あるいは $\mathrm{MgO}$ を含 有するスラグで ESR を扎こなつた. $\mathrm{CaF}_{2}-10 \% \mathrm{MgF}_{2}$ スラグを用いた場合の ESR 後の $\mathrm{Mg}, \mathrm{Al}, \mathrm{O}$ 濃度に およぼす電極中の $\mathrm{Al} ， \mathrm{O}$ 浱度の影響を Fig. 9 に示す. 図から電極中の $\mathrm{Al}$ 浱度の増加に伴い ESR 鋳塊中の $\mathrm{Mg}$ 濃度が增加し， $\mathrm{Al}$ 濃度は電極中の濃度より減少す ることが認められる。また $\mathrm{O}$ 濃度の高い大気溶解電極

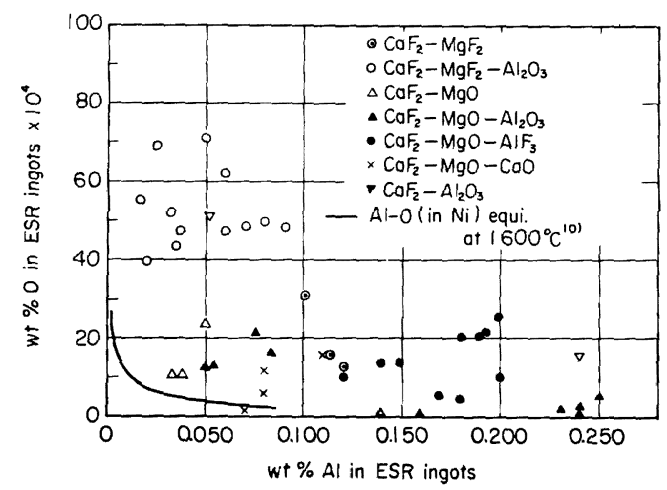

Fig. 11. Relation between the concentration of oxygen and aluminum in the ESR ingot.

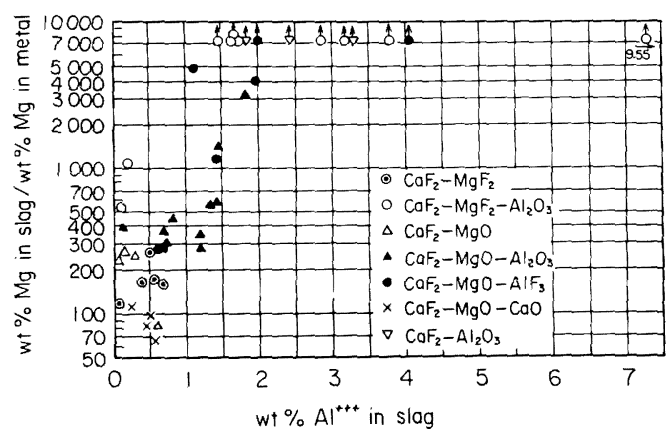

Fig. 12. Influence of the concentration of $\mathrm{Al}^{+++}$ in slag on the distribution ratio of $\mathrm{Mg}$ between slag and metal. 


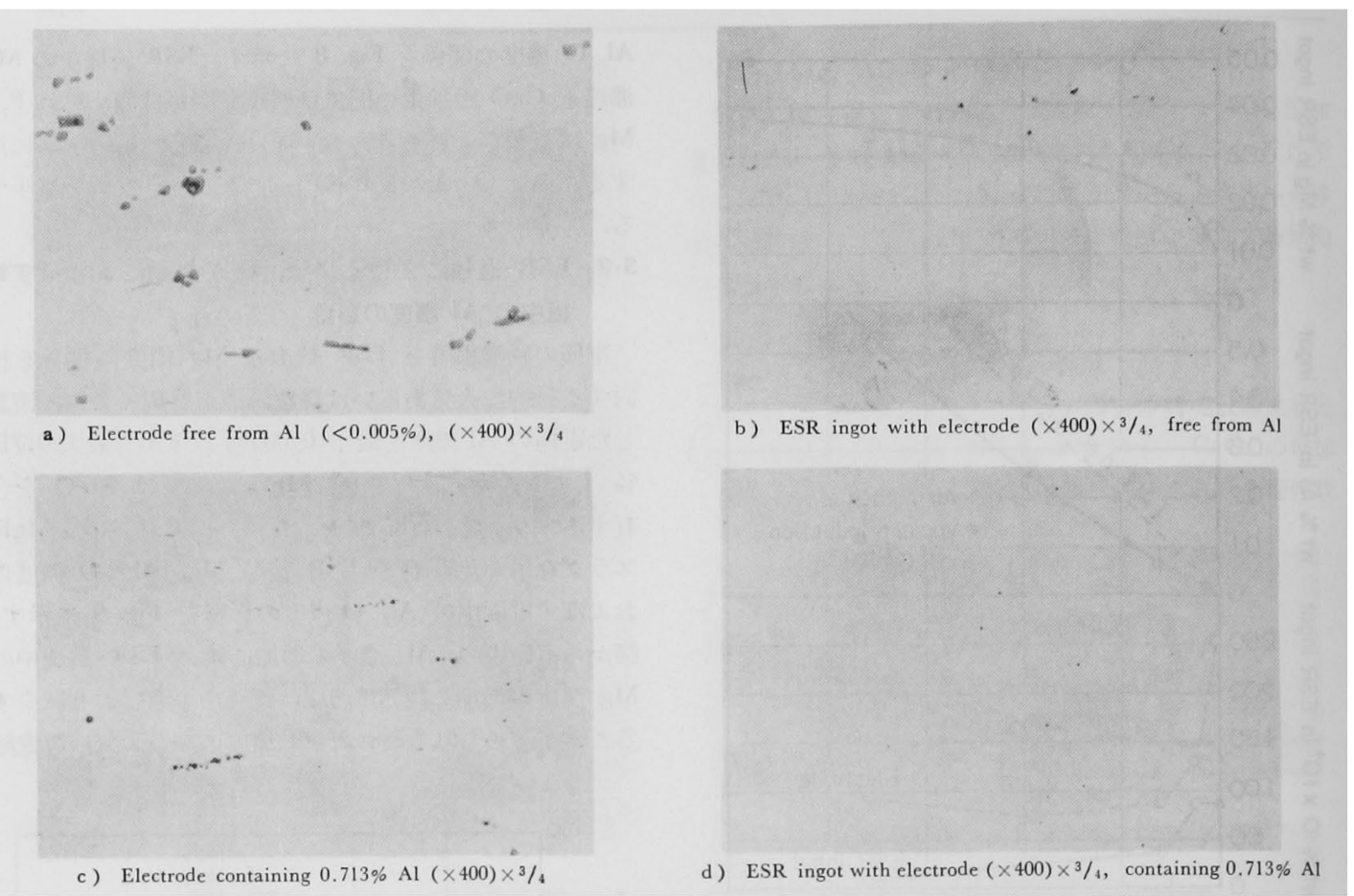

Photo. 5. Influence of the concentration of aluminum on the shape and distribution of nonmetalic inclusion in electrodes and ESR ingots.

を使用した場合の脱酸効果は極めて大きく, ESR 鋳塊 の $\mathrm{O}$ 濃度は電極中の濃度に比較して $50 \%$ 以上減少す る. $\mathrm{Al}$ 濃度が $0.005 \%$ 以下および $0.713 \%$ の電極に ついて, ESR 前後の非金属介在物組織を Photo. 5 に示 す. $\mathrm{Al}$ 濃度の低い電極中ではシリケート系介在物が, $\mathrm{Al}$ を含有する電極中ではアルミナ系介在物が 存在する がこれらは著しく減少し ESR 鋳塊は極めて清浄であ る.

\section{$3.3 \mathrm{ESR}$ 鏏塊中の $\mathrm{O}$ 濃度におよぼす $\mathrm{Al}, \mathrm{Si}$, スラ グ組成の影響}

$\mathrm{ESR}$ 後の鋳塊における $\mathrm{Si}$ 濃度とO 濃度の関係を Fig. 10 亿，また $\mathrm{Al}$ 濃度と $\mathrm{O}$ 濃度の関係を Fig. 11 に 示寸. Fig. 11 には $1600^{\circ} \mathrm{C}$ における純 $\mathrm{Ni}$ 融体中の $\mathrm{Al}-\mathrm{O}$ の平衡曲線 ${ }^{10)}$ を併せて示した.これらの結果から $\mathrm{O}$ 濃度は $\mathrm{Si}$ 濃度には依存せず $\mathrm{Al}$ 濃度およびスラグ 組成への依存性が認められる. ESR 中にスラグからメ タルへの $\mathrm{Mg}$ の移動量が大きい $\mathrm{CaF}_{2}-\mathrm{MgO}$ 系, $\mathrm{CaF}_{2}-$ $\mathrm{MgO}-\mathrm{CaO}$ 系, $\mathrm{CaF}_{2}-\mathrm{MgO}-\mathrm{Al}_{2} \mathrm{O}_{3}\left(\mathrm{Al}_{2} \mathrm{O}_{3} \leqq 5 \%\right)$ 系ス ラグの場合には他の成分系に比較して $\mathrm{O}$ 濃度は低く $\mathrm{CaF}_{2}-\mathrm{Al}_{2} \mathrm{O}_{3}$ 系および $\mathrm{CaF}_{2}-\mathrm{MgF}_{2}-\mathrm{Al}_{2} \mathrm{O}_{3}$ 系の場合には O 濃度が高い。

\section{4 スラグ-メタル間の $\mathbf{M g}$ の分配比}

スラグーメタル間の $\mathrm{Mg}$ の分配比 (= Mg in slag/Mg in metal) におよぼすスラグ中の $\mathrm{Al}+++$ 浱度の影響, お よび ESR 鋳塊中の O 濃度の影響をとれぞれ Fig. 12, Fig. 13 に示す. Fig. 4, Fig. 6 からスラグ中の $\mathrm{Al}_{2} \mathrm{O}_{3}$, $\mathrm{AlF}_{3}$ 濃度が増加するとスラグからメタルへの $\mathrm{Mg}$ の移 動量は減少することが認められたが， Mg の分配比とス ラグ中の $\mathrm{Al}^{+++}$濃度の間には Fig. 12 のごとく相関性が 認められる. すなわち $\mathrm{Al}^{+++}$濃度が増加するに伴い分

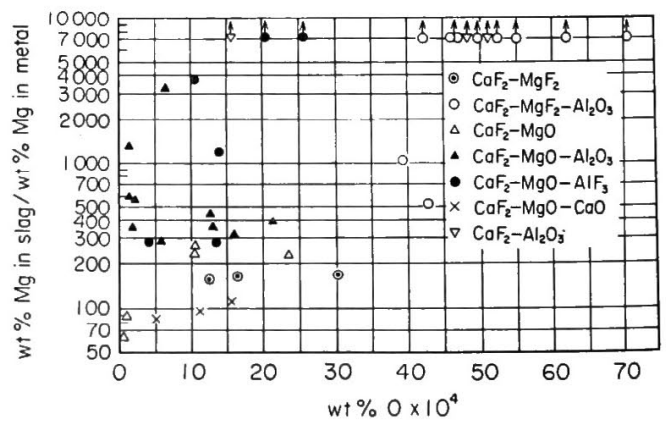

Fig. 13. Influence of the concentration of $\mathrm{O}$ in metal on the dispersion ratio of $\mathrm{Mg}$ between slag and metal. 
配比は大きくなり, $\mathrm{Al}^{+++}$濃度が $2 \%$ 以上に増加する とスラグからメタルへの $\mathrm{Mg}$ の移動はおこなわれなく なる。

$\mathrm{Mg}$ の分配比と $\mathrm{O}$ 濃度との間には, 前者とスラグ中 の $\mathrm{Al}$ 濃度との関係ほど相関性は認められないが, O 濃 度が $40 \mathrm{ppm}$ を越えると分配比は大きくなり，ESR 録 塊に $\mathrm{Mg}$ 方残留し難くなる。

実験に供した各スラグ亲の中では, $\mathrm{CaF}_{2}-\mathrm{MgO}-\mathrm{CaO}$ 系, $\mathrm{CaF}_{2}-\mathrm{MgO}$ 系, $\mathrm{CaF}_{2}-\mathrm{MgF}_{2}$ 系がこれらの条件を 満たし，スラグーメタル間の $\mathrm{Mg}$ の分配比を隇少させる.

\section{4. 考察}

本実験では $\mathrm{Mg}$ を添加しない $\mathrm{Ni}$ 基合金の電極を $\mathrm{MgO}$ あるいは $\mathrm{MgF}_{2}$ を含有するスラグで ESRをおこ なつた場合，ESR 鋳塊に微量の $\mathrm{Mg}$ が残留することが 認められた。

ESR 飞小いてメタル中に $\mathrm{Al}$ ，Si などの脱酸元素が 存在し，スラグ中に $\mathrm{Al}^{+++}, \mathrm{Si}^{4+}, \mathrm{Mg}^{++}$方存在する 場合これらの元素およびイオン間には次のような置換反 応を考えることができる.

$$
\begin{aligned}
& 2[\mathrm{Al}]+3\left(\mathrm{Mg}^{++}\right)=2\left(\mathrm{Al}^{+++}\right)+3[\mathrm{Mg}] \\
& K_{1}=a_{\mathrm{Al}}^{2}{ }^{+++} \cdot a^{3} \mathrm{Mg} / a_{\mathrm{Al}}^{2} \cdot a_{\mathrm{Mg}}^{3}{ }^{++} \\
& {[\mathrm{Si}]+2\left(\mathrm{Mg}^{++}\right)=\left(\mathrm{Si}^{4+}\right)+2[\mathrm{Mg}]} \\
& K_{2}=a_{\mathrm{Si}^{4}}+\cdot a^{2} \mathrm{Mg} / a_{\mathrm{Si}} \cdot a^{2} \mathrm{Mg}^{++} \\
& 3[\mathrm{Si}]+4\left(\mathrm{Al}^{+++}\right)=3\left(\mathrm{Si}^{4+}\right)+4[\mathrm{Al}] \\
& K_{3}=a^{3} \mathrm{Si}^{4+} \cdot a^{4}{ }_{\mathrm{Al} 1} / a^{3} \mathrm{Si}_{1} \cdot a^{4}{ }_{\mathrm{Al}}{ }^{++} \\
& \text {ここで } \\
& a_{\mathrm{Mg}} \quad \text { × タル中の } \mathrm{Mg} \text { の活量 } \\
& a_{\mathrm{Mg}^{++}} \text {=スラグ中の } \mathrm{Mg}^{++} \text {の活量 } \\
& a_{\mathrm{A} 1} \quad \text { × タル中の } \mathrm{Al} \text { の活量 } \\
& a_{\mathrm{Al}}{ }^{++}=\text {スラグ中の } \mathrm{Al}^{+++} \text {の活量 } \\
& a_{\mathrm{Si}} \quad \text { × タル中の } \mathrm{Si} \text { の活量 } \\
& a_{\mathrm{Si}^{4+}}^{4+} \text { =スラグ中の } \mathrm{Si}^{4+} \text { の活量 } \\
& K_{1}, K_{2}, K_{3}=\text { 定数 }
\end{aligned}
$$

$\mathrm{Mg}$ のスラグからメタルへの移動は $\mathrm{MgO}$ あるいは $\mathrm{MgF}_{2}$ として添加したスラグ中の $\mathrm{Mg}^{++}$が (1) 式, (2) 式のごとくメタル中の $\mathrm{Al}, \mathrm{Si}$ などの脱酸元素に よつて還元されることによるものと考えられる.

Fig. 14 および Fig. 15 にはそれぞれ $\mathrm{CaF}_{2}-\mathrm{MgO}$ 系 スラグを用いた場合の ESR 前後の $\mathrm{Al}$ 変化量と $\mathrm{Mg}$ 変 化量の関係および $\mathrm{Si}$ 変化量と $\mathrm{Mg}$ 变化量の関係を示 す. 図中の実線は ESR 鋳塊への $\mathrm{Mg}$ の増加が，（1） または（2）式による Al または Si の酸化と化学量論 的に対応するものとして計算した值である. Fig. 14 か ら明らかなように ESR 鋳塊中の実際の $\mathrm{Mg}$ 濃度の増

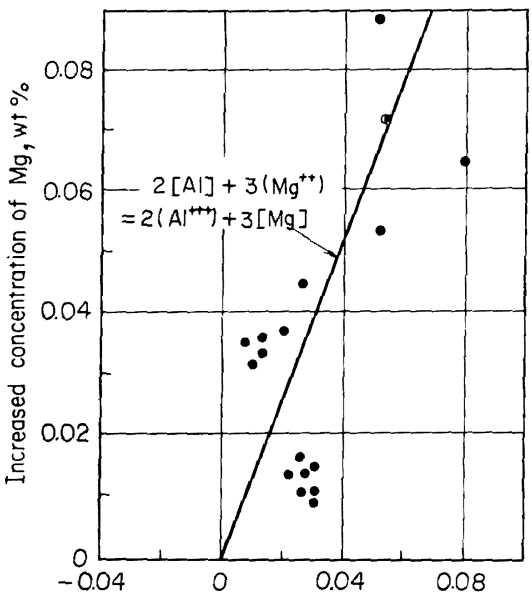

(Al in electrodes-Al in ESR ingots), wt \%

Fig. 14. Relation between the change of the concentration of $\mathrm{Mg}$ and $\mathrm{Al}$ during $\mathrm{ESR}$ in the case of $\mathrm{CaF}_{2}-\mathrm{MgO}$ slag.

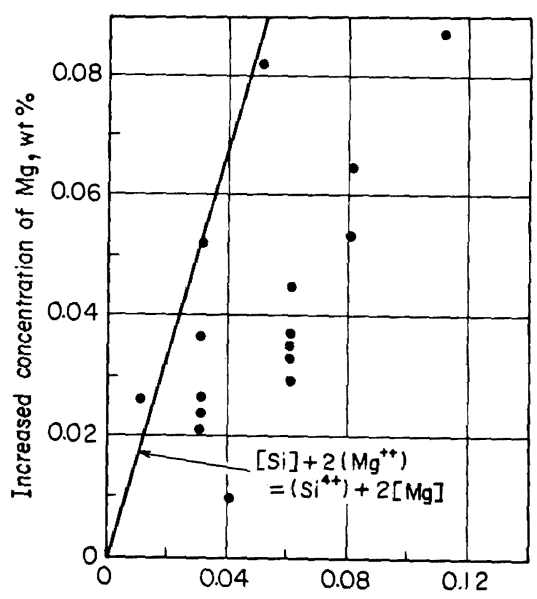

(Si in electrodes-Si in ESR ingots), wt \%

Fig. 15. Relation between the change of the concentration of $\mathrm{Mg}$ and $\mathrm{Si}$ during ESR in the case of $\mathrm{CaF}_{2}-\mathrm{MgO}$ slag.

加量は (1) 式の $\mathrm{Al}$ 濃度の 減少に伴なう $\mathrm{Mg}$ 濃度の 増加量にほぼ相応した值が得られる。

一方, $\mathrm{CaF}_{2}-\mathrm{MgO}-\mathrm{Al}_{2} \mathrm{O}_{3}, \mathrm{CaF}_{2}-\mathrm{MgO}-\mathrm{AlF}_{3}$ などの ようにスラグ中に $\mathrm{Al}^{+++}$を含有するスラグを用いた場 合には， $\mathrm{Al}_{2} \mathrm{O}_{3}, \mathrm{AlF}_{3}$ の増加に伴い $\mathrm{ESR}$ 鋳塊中の $\mathrm{Al}$ 濃度は電極中のその濃度より增加し, また $\mathrm{Al}_{2} \mathrm{O}_{3}, \mathrm{AlF}_{3}$ 添加量兮少ない場合には， $\mathrm{Al}$ 濃度の堌加に加えて $\mathrm{Mg}$ 濃度も増加する現象が認められた。 $\mathrm{CaF}_{2}-\mathrm{MgO}-\mathrm{Al}_{2} \mathrm{O}_{3}$ 系スラグを用いた場合の $\mathrm{ESR}$ 前後の $\mathrm{Al}$ 濃度と $\mathrm{Si}$ 濃度 


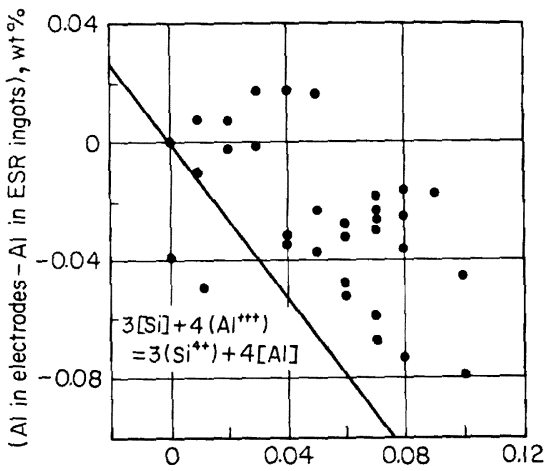

( $S i$ in electrodes-Si in ESR ingots), wt \%

Fig. 16. Relation between the change of the concentration of $\mathrm{Al}$ and $\mathrm{Si}$ during ESR in the case of $\mathrm{CaF}_{2}-\mathrm{MgO}-\mathrm{Al}_{2} \mathrm{O}_{3}$ slag.

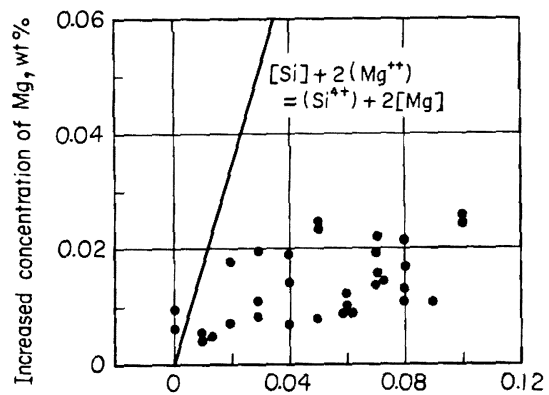

( $S$ i in electrodes-Si in ESR ingots), $w \uparrow \%$

Fig. 17. Relation between the change of the concentration of $\mathrm{Mg}$ and $\mathrm{Si}$ during ESR in the case of $\mathrm{CaF}_{2}-\mathrm{MgO}-\mathrm{Al}_{2} \mathrm{O}_{3}$ slag.

の変化量の関係を Fig. 16 に, $\mathrm{Mg}$ 濃度と $\mathrm{Si}$ 濃度の变 化量の関係を Fig. 17 に示す. 各図中の直線はそれぞれ

(3) 式および (2) 式の $\mathrm{Al}$ と $\mathrm{Si}, \mathrm{Si}$ と $\mathrm{Mg}$ の原子 量比から計算した濃度变化の関係である. $\mathrm{Al}_{2} \mathrm{O}_{3}$ あるい は $\mathrm{AlF}_{3}$ を含有するスラグを用いた場合の ESR 鋳塊に おける Al 濃度の増加は Fig. 16 に示すようにメタル中 の $\mathrm{Si}$ がスラグ中の $\mathrm{Al}++$ を還元することによつても たらされるものと考えられる。また Fig. 17 から ESR 鋳塊中の実際の $\mathrm{Mg}$ 濃度の增加量法 (2) 式の $\mathrm{Si}$ 濃度 の減少に伴う $\mathrm{Mg}$ 濃度の増加量より小さいが， Si 濃度 の減少に伴ない ESR 鋳塊における $\mathrm{Mg}$ 浱度は增加す る傾向が認められる。メタル中に移動した $\mathrm{Mg}$ は蒸気 压が高い元素であるために，蒸発による損失がおこるで あろうが，本実験のごとき小型 ESR 叔の場合には溶湯 の滯留時間が短かい（中心部：約 $1 \mathrm{~min}$ )ために損失量 は少ないものと考えられる。
以上述べたように本実験の $\mathrm{Ni}$ 基合金の ESR 過程で 認められるスラグからメタルへの $\mathrm{Mg}$ の移動は（1)式 あるいは（2)式によつて示されるようなメタル中の AI および Si によるスラグ中の $\mathrm{Mg}^{++}$の還元置換反応に 起因するものと考えられる. したがつてスラグ中への $\mathrm{MgO}$ あるいは $\mathrm{MgF}_{2}$ の增加による $\mathrm{Mg}^{++}$の活量の 増大に伴ないメタル中の $\mathrm{Mg}$ 濃度は増加し，スラグ中 の $\mathrm{Al}^{+++}$の活量あるいはメタル中の $\mathrm{O}$ 浱度か増加す るとスラグーメタル間の $\mathrm{Mg}$ の分配比が大きくなる。

\section{5. 結訔}

実験室的小型 ESR 炉により，Ni基合金（AMS 5754 相当）の ESR 過程における $\mathrm{Mg}, \mathrm{Al}, \mathrm{Si}, \mathrm{O}$ などの挙動 について検討した，得られた結果を要約すると下記のご とくになる.

(1) スラグには $\mathrm{CaF}_{2}-\mathrm{MgF}_{2}, \mathrm{CaF}_{2}-\mathrm{MgO}$ および これらに $\mathrm{Al}_{2} \mathrm{O}_{3}, \mathrm{AlF}_{3}$ を添加した二元系, 三元系を用 いたが，電極中に $\mathrm{Mg}$ を添加しない場合でもスラグか らメタルへの Mg の移動によつて $\mathrm{ESR}$ 鋳塊中の $\mathrm{Mg}$ 濃度が増加する。

(2) スラグ中の $\mathrm{Al}+++$ 濃度の増加およびメタル中 の $\mathrm{O}$ 濃度の増加に伴ないスラグーメタル間の $\mathrm{Mg}$ の分 配比は増大し，前者が $2 \%$ 以上に増加した場合，ある いは後者が $40 \mathrm{ppm}$ 以上になると ESR 後の鋳塊に $\mathrm{Mg}$ は残留し難くなる。

（3）電極中の $\mathrm{Al}$ 濃度の増加に伴ないスラグからメ タルへの Mg の移動量は增加する。

(4) $\mathrm{ESR}$ 後の $\mathrm{O}$ 濃度はメタル中の $\mathrm{Al}$ 濃度およ びスラグ組成に依存する， $\mathrm{CaF}_{2}-\mathrm{MgO}-\mathrm{CaO}$ 系, $\mathrm{CaF}_{2}-$ $\mathrm{MgO}$ 采の場合には他の組成のスラグに比較して鋳塊の $\mathrm{O}$ 濃度は低い。

（5） スラグからメタルへの $\mathrm{Mg}$ の移動はスラグ中 の $\mathrm{Mg}++$ がメタル中の $\mathrm{Al}$ あるいは $\mathrm{Si}$ などによつて 還元されることによるものと考えられる.

(6) スラグ中の $\mathrm{MgO}$ あるいは $\mathrm{MgF}_{2}$ 添加量が増 加すると鋳塊の表面性状は劣化し， $\mathrm{MgO}, \mathrm{MgF}_{2}$ 量が 一定の場合には $\mathrm{Al}_{2} \mathrm{O}_{3}, \mathrm{AlF}_{3}$ の増加に伴い表面性状は 良好となる。

\section{文献}

1) H. J. Klein and $J \cdot W$. Pridjion: Superalloys Processing Proceedings of the 2nd International Conference, AIME (1972), p. B-1

2) C. F. Eliotr, et al.: Proceedings of the 4th International Conference on ESR, (1973), p. 298

3) G. K. Bнat: Proceedings of the International Conference on ESR, (1973), p. 196 
4) C. T. Sims and W. C. Hagel: The Superalloys, John Willey \& Sons, (1972)

5) R.S. Cremisio and D.A. Shinn: Proceedings of the 4th International Conference on ESR, (1973), p. 276

6) $Y u . V$. Latash and $B . I$. Medovar: Electroslag Melting, Izd.-vo Metallurgia, Moscow, (1970)

7) R. H. Nafziger and $R . L$. Lincoln: Cobalt
(1974) 4, p. 79

8 ) $M . I$. KRichevec, et al: Reports of the International Symposium on Special Electrometallugy, Kiev, June, (1972), p. 61

9 ) $G$. Bacon, $A$. Mitchell, and $R$. M. Nishizaki: Met. Trans., 3 (1972) 3, p. 631

10) A. M. Samarin: Production and Application of Clean Steels, (1973), p. 17 